\title{
Comment
}

\section{'Anthropology' challenged: notes for a debate}

Jo ÃO DE PINA-CABRAL University of Lisbon

In January 2006, the international community of anthropologists was confronted with a surprising piece of news. France's principal funding body, the Centre National de la Recherche Scientifique (CNRS), was contemplating striking anthropology out of its disciplinary list, attributing to it a subsidiary position within the field of history. A heated debate ensued concerning anthropology's independent position within the CNRS funding structure. One does not know whether it was thought that anthropology always had been a branch of history or whether it was thought that it always should have been or, alternatively, if the idea was that it was simply irrelevant!

Ultimately, in the face of national and international outcry, the proposal was dropped and the change was not implemented. We were all very pleased about that outcome. Many of us, however, remained preoccupied by it all, feeling that a misunderstanding on that scale should not be treated as an isolated event. Rather, it should be seen as a sign that the public understanding of anthropology is not what it should be, that the issue is in bad need of further debate. ${ }^{1}$ How ironic that this mishap should have occurred on the turf of Marcel Mauss and Lévi-Strauss, where modern anthropology was born!

Now, let it be clear from the start that anthropologists have nothing against history or historians - to the contrary. Never has the dialogue between the two disciplines been richer than over the past two decades. Their disciplinary history, however, remains radically distinct. Their contributions to the humanities and the social sciences are not in competition; rather they are mutually indispensable parts of the more general socio-scientific field that modernity has launched.

Today, socio-cultural anthropology is emerging out of the crisis of self-doubt that attacked it during the post-colonial era. In the Portuguese-speaking, Spanish-speaking, and German-speaking worlds, the discipline is once again demonstrating a heightened capacity for renovation and for dealing with highly topical, fully contemporary issues. In France too, anthropologists are a lively lot, being fully integrated into global scientific interchanges. Theoretically they are active, methodologically they have provided new and creative responses to the issues of the day, geographically they cover an impressively large area of the ethnographic map. 
What is disturbing about the CNRS event is how easily 'anthropology', as a field of disciplinary endeavour with a long and valuable history, could be misrepresented so as (a) not to take into account its distinct theoretical legacy, which differentiates it from history and the other sciences sociales et humaines, and (b) to fail to perceive the nature of anthropology's engagement with temporality. It could be argued that anthropologists are a type of 'contemporary historian' - as our standard methodology is ethnography with participant observation. That, however, is missing the point that anthropology is not and has never been bound by a discourse of temporal (and spatial) specificity, but rather has, if anything, promoted temporal (and spatial) overreach. Not only is our work very distinct from that typically carried out by 'contemporary historians', but anthropology also has a specific theoretical and methodological legacy that cannot simply be discarded.

The moral of all this, however, is that, in the end, anthropologists are partly responsible for this confusion as it arises from our own incapacity to declare openly that we have freed ourselves from the 'primitivist' self-definition. The favoured French label of ethnologie, with its traditionalist and ruralist implications, clearly also helps this sort of misapprehension. ${ }^{2}$ Yet the largest majority of anthropologists/ethnologues have long ago discarded the notion of primitivism and the accompanying intellectual framework which conceives the search for the essence of humanity as a search for what existed 'originally', 'before', or under 'primitive/savage/non-modern' conditions (see Kuper 1988).

One of the most shocking examples of how anthropologists have failed to pass on the message to the generally informed public is Anthony Giddens's essay on 'The future of anthropology' (1996). In the mid-1990s, thirty years after anthropology started actively engaging the issue, Giddens finally discovered that 'the exotic, far-away places which were once so inaccessible' had vanished! This, he reckons, is a problem for anthropology, and so he lays down his now infamous definition of our discipline: 'A discipline which deals with an evaporating subject-matter, staking claim to a method which it shares with the rest of the social sciences anyway, and deficient in its core theoretical traditions' (1996: 123).

If this is written by a sociologist in the 1990s, one wonders what interdisciplinarity can ever come to! But then Giddens generously concedes that he can see some areas where anthropology may still be relevant, and he lists three examples: 'the resurgence of ethnicity', 'the revival of "tribalism" ', and 'the continuing importance of religion and ritual'! Finally, he declares that some future may exist for anthropology if it agrees to contribute "to the collective effort that the social sciences as a whole need to make to confront a social world which has changed almost out of recognition in a few short years' (1996: 126).

Anthony Giddens played a decisive role in the institutional framework of the social sciences in late twentieth-century Britain. That he, of all people, should continue to understand anthropology through the prism of 'primitivism' is a clear sign that we have not been able to pass on the message. Yes, anthropology did 'come into modernity', so to speak, on the back of the primitivist trope both in its exotic manifestation in colonial ethnology/anthropology (Völkerkunde) and through the nationalistic project of ethnology/folklore (Volkskunde). Most anthropologists, over the past decades, however, have operated under the notion that this heritage has been discarded. Despite this presumption, anthropology continues to be read as a study of the primitive both by the general public and by the non-specialist scientific public. Troubling 
signs of this are apparent not only in Giddens's comments or in the CNRS mishap but on yet other fronts as well.

The primitivist understanding of 'anthropology' has become so widespread that we have almost stopped being surprised by it. For example, in a recent issue of National Geographic Magazine (Portuguese edition, Feb. 2006) one can read the following caption next to a charming photograph of a couple kissing whilst being applauded by guests outside a wedding chapel:

bonds. Marriage enthrals yet another couple in the Italian city of Varese. In spite of the euphoria of the newly wedded couple, the anthropologist ... sustains that the creation of bonds of affect in the couple is guided by the mating instinct, which originates in the most primitive sector of our brain. 'See this man's joy,' comments [the anthropologist]. 'He has just conquered the most important thing in his life: a chance to transmit his DNA' (p. 43).

Now, such statements are so common that one is hardly surprised by them. Yet what is the percentage of those who are today professionally entitled to be called 'anthropologist', who teach in our graduate or postgraduate schools, and present papers in our professional conferences, that would back up such a statement? Note that the issue here is not one of interdisciplinary miscommunication between 'physical anthropologists', who work within the theoretical and methodological framework of the life sciences, and 'social or cultural anthropologists' working within the framework of the social sciences and humanities. Statements of this nature are not supported by contemporary standards in either disciplinary area.

Of course, it may be argued, anyone is perfectly entitled to elaborate any notion they should wish to and, after all, National Geographic is not a professional journal. That, however, misses the point that, by referring to their interviewee as an 'anthropologist', the journal is legitimating before the general public yet another version of the primitivist trope. The supposed 'scientific' nature of this person's statement is further validated by referring to a 'scientific' entity the general public knows of but does not understand, that is, the DNA that supposedly manifests itself in the 'most primitive' recesses of the bridegroom's brain and determines for him what is most important in his life.

Let such examples be a warning to anthropologists throughout the world. Immersed as we have been in post-colonial self-criticism and departmental politics, ${ }^{3}$ we have failed to be explicit. We have been too afraid of concronting the issue of the intellectual vocation of our discipline while we have so engaged ourselves in interdisciplinarity that we have jeopardized our disciplinary future.

The time has come for a more serious engagement with the past of our discipline which will overcome the political phantoms of the colonial era and of the Romantic debate on nationalism as much as it takes on board the implications of a more contemporary and informed philosophical epistemology. We need, furthermore, to make clear the nature of our disciplinary vocation within the social sciences, ${ }^{4}$ overcoming the definitional straitjacket that we inherited from this history which wedged anthropology between nationalism and primitivism.

Lacking the certainties of a prophet, I expect that each practitioner will find his or her own specific mode of response to these challenges. Notwithstanding, judging from the liveliness of the debates and the empirical wealth of the research presented year after year in our conferences, I have no doubt that anthropology as a disciplinary field is sufficiently strong to take on a debate which we have deferred for far too long. 
To my mind there are three unavoidable axes of contextualization for this debate: the political axis, the epistemological axis, and the ethical axis. Each of these has to be addressed if we are going to debate the anthropological vocation. I will be brief here, as some of these issues have been argued at greater length elsewhere (see Pina-Cabral 2004, 2005a, 2005b).

The political axis becomes apparent if we contrast the modes of production characterizing anthropology during the colonial and the immediately post-colonial periods with those in effect today. As a social science, anthropology is a universalist type of knowledge, marked by its history but not owned by any specific type of practitioner; as soon as anthropologists started providing useful insights about the populations that laboured under the yoke of colonialism, their knowledge started to become relevant to the more informed members of those very same populations (see Lyn Schumaker's Africanizing anthropology, 2001). In this way, today, anthropology can be seen as operating under a global condition. In short, in a world where anyone can both be a native and an ethnographer, Volkskunde/Völkerkunde, anthropologie/ethnologie collapse into each other.

Such a tendency is nothing new in anthropology, but in this our twenty-first century marked by instant global communication, it has come to full fruition: there are anthropology departments all around the globe and almost anyone who can achieve university education can choose to become an anthropologist. In a recent article in defence of cosmopolitanism, Kwame Anthony Appiah (2006) argued that people's adoption of globalized practices and artefacts is patently compatible with their allegiance to local and historically specific cultural worlds. He asked, 'and what can you tell about people's souls from the fact that they drink Coca-Cola?' Much like drinking Coca-Cola, the practice of anthropology does not contradict people's localized political, religious, and ethnic identities. Thus, we find that the right to dialogue with the anthropological canon is being claimed by people, for example, in China (e.g. Tam 1998), Serbia (e.g. Boskovic 2005), Brazil (e.g. Trajano Filho \& Lins Ribeiro 2004), Portugal (Pina-Cabral 1992a), and Japan (e.g. Ota 2002). Anyone's lifeworld can become the object of ethnographic exploration. ${ }^{5}$ Therefore, as ethnography engages more and more diversified social contexts and cultural environments, anyone who is an ethnographer has to confront the possibility of being an object of ethnography. ${ }^{6}$

This has two very distinct political implications. On the one hand, ethnography becomes an area for the reflexive exercise of anti-hegemonic imagination; on the other hand, insofar as ethnography is an exercise in interpretation, ethnographers from 'far away' are bound to dialogue with ethnographers from 'nearby'.? It then becomes legitimate to question the modes through which this type of reflexivity is systematically being silenced by, for example, the nearly universal practice of those who publish in English of not quoting the works of colleagues who publish in the language of the region they study, or the practice of using national or geo-political boundaries as implicit and unquestioned frames for socio-cultural ethnographic contextualization (see Pina-Cabral 1989).

From a theoretical point of view, the 'global nature' of anthropological knowledge raises issues concerning the way in which the universal right of access to the practice of science enters into conflict with culturally specific worldviews. ${ }^{8}$ I argue that we have to intensify the effort to eradicate Eurocentric modernist assumptions from anthropological theory and methodology. ${ }^{9}$ 
Now, as our Brazilian colleagues have been noting for a while (see Peirano 1991), the fact that the anthropological disciplinary tradition has come to be adopted by people from all over the world should surely have challenged some of the more engrained perspectival practices that continue to haunt our discipline as survivals, excuse the mixed metaphor, of the earlier primitivist posture - when cultural difference was silently transformed into political inequality by means of a temporal device. As one reads today with hindsight, for example, such a classic as Mary Douglas's Purity and danger (1966), one cannot but be struck by the way in which, right in the middle of the 1960 post-colonial crisis, the perspectival 'we' continued to be used to create a common ground between the anthropological analyst and her supposed readers, typecasting both of them as 'modern', 'Euro-American'/'Western' and 'educated middle-class'. Later on, in works such as Louis Dumont's essays of the early 1980s, this tendency was taken to an extreme almost of proselytism: 'the individual, autonomous, and thus essentially non-social moral being, who carries out paramount values ..., is found primarily in our modern ideology of man and society' (1985: 94).

Later still, in the late 1980 s and early 1990s, under the influence of David Schneider, rather than working at globalizing the perspectival 'we' of the anthropological analyst, a trick was invented which allowed for epistemological defeatism: the notion came to be accepted that a 'culture' as a 'system of symbols' can be describable in 'its own terms' and that, therefore, 'we' could safely describe 'ourselves' (Schneider 1980 [1968]: 1-18). ${ }^{10}$

Even though a lot of very serious and valuable work was carried out using this epistemological sleight of hand, the truth is that many of 'us' (anthropologists from less central areas of the world) do not feel comfortable with perspectival labels that are supposed to embrace all anthropologists and their readers in this way. This is the case, for example, with the now famous 'Euro-American, and especially those of the British sort' label, which Marilyn Strathern has been using to perform the peculiar foundational role of both subject and object of her insightful analyses (e.g. 2006: 196, but already present since After nature, 1992). Cultural 'alterity' is exacerbated to such a point that the only safe solution for the acquisition of legitimate knowledge becomes for the subject and the object to conjoin. The problem is that, cultures being fields of power, no 'cultural symbol' is beyond dispute, thus no culture can describe itself. Schneider's clumsy attempts to resolve the problems caused by ethnicity and class to his model of 'American kinship' are perhaps one of the best examples of just what is at stake (1980 [1968]: 122).

Far from me to deny the effect that a writer's social position has on her view of what she writes. My point is that the perspectival 'we' presumes an identity between reader and writer ${ }^{11}$ that must not be presumed. Numerically, today, many if not most readers of Mary Douglas and Dumont (or David Schneider and Marilyn Strathern, for that matter) are no longer better described as 'Euro-American/Western'. But even those readers, such as myself (see also Ota 2002), who might be describable as 'European' or 'Westernized', cannot fail to notice that these modes of perspectival labelling typecast the anthropological subject and her reader, thus operating a process of exacerbation of authenticity and silencing of continuities.

In order to take a fuller cognizance of the fact that all natives can be ethnographers, we have to come to terms with the fact that all ethnographers may be, and remain, natives. This, as we have seen, brings us to the second axis of debate, that concerning the epistemological nature of anthropological knowledge. 
Ever since the mid-1970s, anthropologists have undertaken a thorough and pitiless examination of anthropological knowledge. Nowhere else have the tools of reflexivity been used in so trenchant a manner as in anthropological self-examination. This search was highly profitable and definitely constitutes one of the more valuable aspects of our disciplinary heritage. However, by the mid-1990s, it had congealed into an implicit (i.e. not theorized) attitude of general disbelief. It is a pity that more of us did not listen to Steven Collins when, long ago, he warned anthropologists that 'we must learn to distinguish ... between a properly philosophical epistemology and a sociologically informed history of ideas' (1985: 76).

Even though only rarely did one find an anthropologist willing openly to cast doubt on the value of empirical fact-gathering, the truth is that epistemological scepticism became deeply pervasive. Theoretically, it was all very vague, rarely amounting to more than a kind of culturalist depression - such as manifested in Schneider's famous disparagement of people who believe in the existence of 'things' (see Schneider 1984: vii). For all that, its effects were highly destructive and prevented anthropologists from addressing head-on the scientific nature of their professional endeavours.

Philosophers call approaches of this kind 'deflationist', which maintain that truth is simply not a property, it does not point to any real characteristic of our thoughts or beliefs (see Lynch 1998: 111-18). A singular result of holding such views is that, being disappointed with the material world, people who hold them turn for refuge in the world of meaning. A tendency rises to focus on discursive behaviour - on language games. In anthropology, this turn of attention opened out a number of fascinating perspectives but, in the end, it came to pose practical problems as it threw into question the very purpose of the anthropological enterprise.

As a matter of fact, this is an area where Giddens makes a useful contribution in his otherwise absurdly arrogant paper. He identifies quite correctly that the so-called 'crisis' of anthropology ${ }^{12}$ is less of a crisis in the actual practice of anthropology than the result of a misguided (i.e. epistemologically ill-conceived) theory of meaning: 'those who speak of a crisis of representation in anthropology, or who see anthropological work merely as a species of creative fiction, are the victims of ... a false theory of meaning' which 'can be traced right back to the origins of structuralist linguistics in Saussure' that understand meaning 'in relation to the play of signifiers, not - as it should be - in the context of practical experience' (1996: 124).

The ghost of positivism hangs over any discussion of the scientific nature of anthropological knowledge, paralysing us before the need to state explicitly that the knowledge we produce as anthropologists is not just any kind of knowledge but a specific type: scientific knowledge. ${ }^{13}$ Indeed, if our 'anthropology' is going to be compatible with a globalized world and with our multifaceted socio-cultural belonging, it must consciously eschew cultural specificity. In short, our efforts as scientists must be guided by universalistic aims. Of course, we can point to instances in the past (and presume instances in the future) when the local culture of the scientist has affected (or will affect) anthropological knowledge; post-colonial self-critique provides many such instances. This must not, however, be taken despondently as a sign of inevitable epistemological doom. It rather indicates that anthropological knowledge is open to scientific critical improvement and that anthropologists can produce a type of knowledge of universalistic relevance.

The time has come for us to admit that, if we continue to cite anthropologists of the past, it is not because of any number of vaguely shameful perspectival dispositions 
(Eurocentrism, patriarchalism, Western-ness, plain lack of imagination, etc.), but simply because the arguments we make would be destitute of relevant anthropological context if they were not related to the debates of old. Recently, a tendency has been openly expressed by colleagues working in the more prestigious universities of the United States of America, Britain, and France to debase the anthropological heritage, at times even to opt out of the disciplinary title altogether by adopting circumstantial object-orientated titles in the 'Studies' mould or by favouring 'interdisciplinarity' (see Marilyn Strathern's insightful criticism of this trend - 2006).

Claiming that the disciplinary canon is politically compromised and that it is, therefore, not useful for present concerns, they go as far as to stop teaching courses in 'Introduction to Anthropology' to their students! This obliges their students to reinvent the well-tried arguments of old and prevents them from benefiting from anthropology's already lengthy theoretical and empirical heritage. Recently, for example, the journal American Ethnologist discussed the timeworn issue of 'marriage' and its relation to patriarchalism (32: 1, 2005). According to the author who was invited to write the main paper, all arguments preceding David Schneider's change of mind in the mid1980 s are useless as they are 'classic kinship theory' - she not only rejects them, she shows that she has little knowledge of their content (Blackwood 2005: 5), as the commentators in fact suggest (e.g. Strathern 2005).

Now, the international canon was of course formed within history - I would be the last to deny that or to deny that history is shaped by hegemonic powers - but the fact is that the masters of the past are the only tool we have to protect us from the silencing work of the masters of the future. I refer both to the hegemonies that today are in the air and to the ones that will arise in the future - for history, contrary to what some people seem to think once again, has not stopped. In short, the canon is both a product of power-imbued history and a tool for negotiating that power.

These colleagues - whom I call 'presentists' because they believe they can reinvent knowledge in less compromised terms by cutting with the past - are oblivious to the fact that scientists of the past were, on the whole, as honest and well-meaning as they are. If the anthropology of the past was compromised by the powerful imperial ideologies of the past, how can present anthropology fail to be compromised in the same way? After all, in the face of a world where hegemonic power is not any the less marked than it was a century ago, the political correctness of the presentists from the centre - whether or not their personal histories originated in a more marginal region - sounds as suspect as the political correctness of European missionary anthropologists once sounded. The imperialist centrality of today's presentists is as invisible to them as the imperialist centrality of the anthropologists of the colonial era was.

The one thing that protects 'us' - anthropologists from around the globe, margins and centres - from the presentists, who today are trying to reduce to irrelevance the parts of the global intellectual heritage that they do not condone, is that they too live in history, they too are the products of imperialism; they too are politically correct only because of what they manage to push into the shade. Yoshinobu Ota points in this direction when he asks whether anthropology could not be used 'to unmake subalternity' (2002: 80). By silencing the canon, the presentists are denying the relevance of the work of all of those who do not have as much access to the loci of scientific hegemony as they do (loci which are, today, patently manipulated by the apparatus of information control that surrounds academic publication). 
The question of the scientific nature of anthropological knowledge has broader implications, however, as it connects directly with the third axis of debate, which is the ethical nature of the anthropologist's relations to the objects of his or her study. To be brief, we must address head-on the issue of what sort of 'anthropology' (in the sense of knowledge of what is human) it is that we practice. If we do not we cannot be surprised if others continue to read us through the lens of the prism of primitivism.

The critique of the sociocentric implications of received anthropological wisdom is being undertaken in a challenging manner by an increasing number of colleagues but, on the whole, we continue to operate under the presumption that anthropologists study 'cultures' or 'societies' and that 'individuals' are the elementary constituents of society. This entraps us in the old sociocentric quandary concerning the 'logical origins of society' (see Badcock 1975: 26, 33ff.). Our analytic dispositions do not favour the study of the ethical links of co-responsibility upon which all human sociality is grounded and without which no ethnography would be possible.

I adopt here Emmanuel Levinas's critique of the totalizing logic inscribed in the history of European thinking, which leads us implicitly to treat the distinction between us and them, self and alterity, 'as the logical distinction of parts belonging to a divided whole, which rigorously reciprocal relations unite into a whole' (1996: 165, author's own emphasis). Levinas urges us to question the sociocentric dispositions 'according to which, in human multiplicity, the ego would be reduced to a part of a Whole, which reconstitutes itself in the image of an organism - or a concept - whose unity is the coherence of its members, or a comprehensive structure' (1996: 165). Anthropologists have too long collapsed the distinction between morals (which are bound by institutions and culturally specific rules) and ethics (which arise from human co-presence and mutual co-constitution). Ethical relations are at the origin of our sociality (both from a logical point of view and from an ontogenetic point of view, see Toren 2004) and they are therefore necessary for the constitution of human agents and for their internalization of the rules of morality. They precede and superimpose upon morals. How, then, can we understand the very possibility of ethnography without reference to ethics?

Yet the recognition that the very practice of anthropology presupposes relations of an ethical nature brings with itself a whole world of implications concerning the need for a theoretically more explicit formulation of the concept of humanity and its frontiers. Whilst philosophers have debated this issue at length, ${ }^{14}$ anthropologists have shunned it. This has exposed them to the problems which result from having an exogenous definition imposed upon their discipline.

I propose that, willy-nilly, anthropologists have to enter the fray concerning humanity and the human condition. Only carrying out such an exorcism will we be able to claim for our own the strong and particular discipline of anthropology.

\section{NOTES}

\footnotetext{
${ }^{1}$ A panel has been convened by Junji Koizumi (Osaka University) and myself to debate these issues: 'The Public Image of Anthropology', EASA 2006 Bristol Conference under the auspices of the World Council of Anthropological Associations (WCAA).

${ }^{2}$ See Luiz Fernando Duarte's (1995) paper on the philosophical dilemma that underwrites the history of the social sciences in attempting to integrate the analytical logic of scientific universalism with the holist, synthetic logic of the Romantic heritage. The various versions of the nominal dualism of our discipline that still characterize it today in most countries of 'continental' Europe are a sure sign that this conflict continues to play its role.
} 
${ }^{3}$ And there are obvious benefits in deferring departmental confrontations and increasing departmental endowments by pretending not to notice that we are undersigning the 'primitivist' definition in accepting the institutional association with 'physical anthropology' in continental Europe or with 'the four fields' in the United States.

${ }^{4}$ And, again, to that extent, Giddens has a point when he calls anthropology to 'confront a social world', and to start 'getting to grips with the extraordinary changes now transforming all our lives' (1996: 126). I am only surprised that he has not noticed that we have been doing it for a very long time already.

${ }^{5}$ French journals such as Terrain have been at the forefront of this methodological exercise (http://terrain.revues.org/).

${ }^{6}$ See Ota's insightful comments on this point (2002).

7 I avoid using the formulation of 'anthropology at home' as it ultimately presumes that ethnographic knowledge is of the same nature as the knowledge we have of our lifeworlds. This is one of the more dangerous fallacies raised by the metaphor of 'translation' used to describe ethnographic work (see Pina-Cabral 1992b).

${ }_{8}^{8}$ am grateful to Gustavo Lins Ribeiro and Federico Neiburg for their insightful views concerning these issues.

${ }^{9}$ I have in mind debates such as that which was carried out in the European Association of Social Anthropologists 2000 Kraków meeting concerning secularism and anthropology (see Stewart, Pina-Cabral, Yalçin-Heckmann, Gellner \& Kapferer 2001).

${ }^{10}$ Thus, in American kinship: a cultural account, kinship being a 'European' concept, Schneider claims to be studying kinship it its 'pure form' (1980 [1968]: viii). In his words, 'the study of kinship derives directly and practically unaltered from the ethnoepistemology of European culture' (1984: 175).

${ }^{11}$ As well as among those whom it postulates as perspectivally 'them', the natives.

${ }^{12}$ One of the most poignant examples of the belief in this crisis is Richard Fox's declarations concerning the dire 'need for new research agendas' in his President's Report of the Wenner-Gren Foundation for 2002 (2003: 3-4).

${ }^{13}$ A debate over such pertinent notions as Bourdieu's concept of champ (field: e.g. 1994) is long overdue.

${ }^{14}$ I have in mind such discussions as Donald Davidson's 'Rational animals' (2001), Philippa Foot's Natural goodness (2001), and Peter Singer's 'All animals are equal' (1986).

\section{REFERENCES}

APPIAH, K.A. 2006. The case for contamination. The New York Times Magazine 1 Jan. (available on-line: http://www.nytimes.com/2006/01/01/magazine/01 cosmopolitan.html).

BADCOCK, C.R. 1975. Lévi-Strauss: structuralism and sociological theory. London: Hutchinson.

BLACKWOOD, E. 2005. Wedding bell blues: marriage, missing men, and matrifocal follies. American Ethnologist 32: 1, 3-19.

Boskovic, A. 2005. Socio-cultural anthropology today - an overview. Campos - Revista de Antropologia Social 6: 1/2, 11-26.

BouRdieu, P. 1994. Un acte désintéressé est-il possible? In Raisons pratiques: sur la théorie de I'action, P. Bourdieu, 147-74. Paris: Seuil.

Coluins, S. 1985. Categories, concepts or predicaments? Remarks on Mauss's use of philosophical terminology. In The category of the person: anthropology, philosophy, history (eds) M. Carrithers, S. Collins \& S. Lukes, 46-82. Cambridge: University Press.

DAvidson, D. 2001. Rational animals. In Subjective, intersubjective, objective, D. Davidson, 95-106. Oxford: Clarendon Press.

Douglas, M. 1966. Purity and danger. Harmondsworth: Penguin.

DUARTE, L.F. 1995. Formação e ensino na antropologia social: os dilemmas da universalização romântica. In O ensino da antropologia: temas para discussão (ed.) J. Pacheco de Oliveira, 10-17. Rio de Janeiro: ABA.

DUMONT, L. 1985. A modified view of our origins: the Christian beginings of modern individualism. In The category of the person: anthropology, philosophy, history (eds) M. Carrithers, S. Collins \& S. Lukes, 93-122. Cambridge: University Press.

Foot, P. 2001. Natural goodness. Oxford: Clarendon Press. 
Fox, R. 2003. President's Report: new support at the foundation for 'early-career' scholars. In Report and Financial Statements for 2002. Wenner-Gren Foundation for Anthropological Research, New York.

GIDDENS, A. 1996. The future of anthropology. In In defence of sociology: essays, interpretations and rejoinders, A. Giddens, 121-6. Cambridge: Polity Press.

KUPER, A. 1988. The invention of primitive society: transformations of an illusion. New York: Routledge.

LeVINAS, E. 1996. Basic philosophical writings (eds) A. Peperzak, S. Critchley \& R. Bernasconi. Bloomington: Indiana University Press.

LYNCH, M.P. 1998. Truth in context: an essay on pluralism and objectivity. Cambridge, Mass.: MIT Press.

OтA, Y. 2002. Culture and anthropology in ethnographic modernity. In Anthropology beyond culture (eds) R. Fox \& B. King, 61-80. Oxford: Berg.

PEIRANO, M.G.S. 1991. Uma antropologia plural: três experiências contemporâneas. Brasília: Editora UNB.

PINA-CABRAL, J. de 1989. The Mediterranean as a category of regional comparison: a critical approach. Current Anthropology 30, 399-406.

— 1992a. Anthropologie et identité nationale au Portugal. Gradhiva II, 31-45.

1992b. Against translation. In Europeans observed (eds) J. de Pina-Cabral \& J. Campbell, 1-23. London: St Antony/Macmillan.

2004. Uma história de sucesso: a antropologia brasileira vista de longe. In O campo da anthropologia (eds) W. Trajano Filho \& G. Lins Ribeiro, 249-66. Recife: ABA.

2005a. The future of social anthropology. Social Anthropology 13, 119-28.

$2005 \mathrm{~b}$. The canon and the human condition: challenges facing anthropology today. Unpublished lecture at the Vienna Academy of Sciences, October.

SCHNEIDER, D. 1980 [1968]. American kinship: a cultural account (Second edition). Chicago: University Press.

1984. A critique of the study of kinship. Ann Arbor: University of Michigan Press.

SCHUMAKER, L. 2001. Africanizing anthropology. Durham N.C.: Duke University Press.

SINGER, P. (1986). All animals are equal. In Applied ethics (ed.) P. Singer, 215-28. Oxford: University Press.

Stewart, C., J. de Pina-Cabral, L. Yalçin-Heckmann, D.N. Gellner \& B. Kapferer 2001. Secularism: personal values and professional evaluations. Social Anthropology 9, 323-44.

Strathern, M. 1992. After nature: English kinship in the late twentieth century. Cambridge: University Press.

2005. Missing men. American Ethnologist 32: 1, 28-9.

2006. A community of critics? Thoughts on new knowledge. Journal of the Royal Anthropological Institute (N.S.) 12, 191-209.

TAM, S.M. 1998. Teaching as 'culturalization': reflections on Hongkong-specific anthropological pedagogy. In On the South China track: perspectives on anthropological research and teaching (ed.) S.C.H. Cheung, 199-210. Hong Kong Institute of Asia-Pacific Studies, The Chinese University of Hong Kong.

TOREN, C. 2004. Becoming a Christian in Fiji: an ethnographic study of ontogeny. Journal of the Royal Anthropological Institute (N.S.) 10, 222-40.

Trajano Filho, W. \& G. Lins Ribeiro (eds) 2004. O campo da anthropologia. Recife: ABA.

\section{« Par-delà l'être » : émergence d'une narration de la souffrance au Vietnam}

\section{Résumé}

Mêlant ethnographie et récits littéraires, l'article explore la relation réciproque entre souffrance et agency. Il décrit comment les jeunes femmes vietnamiennes utilisent la narration pour trouver un sens à la souffrance causée par une fausse couche tardive. Visant à élargir l'utilisation anthropologique du concept de souffrance humaine, l'auteur montre que les études tendent à négliger l'importance de l'agency et de l'imagination, qui s'articule sur la souffrance enracinée dans les forces structurelles. L'auteur affirme que cette négligence doit être comprise dans le contexte de conditions épistémologiques et éthiques particulières dans lesquelles sont produites les études anthropologiques de la souffrance humaine, et qu'une 
analyse plus attentive des engagements humains desquels sont issus les récits ethnographiques peut introduire dans la réflexion non seulement le mal que les forces sociales peuvent infliger aux individus, mais aussi les capacités d'action et d'imagination de ceux-ci.

João de Pina-Cabral (D.Phil., Oxon 1982) is Research Co-ordinator at the Institute of Social Sciences, University of Lisbon, and was President of the Portuguese Association of Anthropology (1989-91) and President of the European Association of Social Anthropologists (2003-5). His principal monographs are: Sons of Adam, daughters of Eve: the peasant worldview of the Alto Minho (NW Portugal) (Oxford 1986); Os contextos da antropologia (Lisbon 1992) and Between China and Europe: person, culture and emotion in Macao (LSE Monographs, 2002).

Institute of Social Sciences, University of Lisbon, Av. A Bettencourt 9, 1600-189, Lisbon, Portugal. Pina.Cabral@ics.ul.pt 